\title{
KESIAPAN GURU SEKOLAH AVICENNA JAGAKARSA \\ DALAM MELAKSANAKAN E- LEARNING DI MASA PANDEMI COVID-19
}

\author{
Kristiningsih \\ Program Studi Teknik Informatika, Universitas Indraprasta PGRI Jakarta \\ Email: kriswidaryanto@gmail.com
}

\begin{abstract}
Abstrak
Tujuan dari penelitian ini adalah untuk mengetahui bagaimana kesiapan pembelajaran e-learning saat pandemi COVID-19 di SMA Avicenna Jagakarsa dan untuk mengetahui faktor-faktor apa saja yang masih kurang dan perlu diperbaiki. Model E-Learning Readiness yang akan digunakan dalam penelitian ini adalah model e-learning readiness (ELR) Aydin \& Tasci dengan skala penilaiannya yang dikelompokkan dalam empat faktor. Faktor-faktor tersebut yaitu manusia, pengembangan diri, teknologi, dan inovasi. E-learning readiness tidak hanya bisa digunakan dalam persiapannya saja, tetapi juga dapat digunakan oleh organisasi atau lembaga yang telah menerapkan e-learning. Metode penelitian ini menggunakan kuesioner dengan pendekatan kuantitatif yang bersifat deskriptif, yaitu dengan menggambarkan atau mendiskripsikan fenomena-fenomena yang ada, baik fenomena yang bersifat alamiah ataupun rekayasa manusia berdasarkan model e-learning readiness (ELR) Aydin \& Tasci. Hasil penelitian menunjukan bahwa Guru Sekolah Avicenna Jagakarsa mempunyai indeks kesiapan e-learning skor ELR keseluruhan $\bar{X}=4,31$. Hal tersebut menunjukkan bahwa Sekolah Avicenna Jagakarsa telah siap dalam menerapkan e-learning akan tetapi masih perlu adanya peningkatan.
\end{abstract}

Kata Kunci : e- learning, e- learning readines, ELR, covid- 19

\begin{abstract}
The purpose of this research is to find out e-learning readiness during the COVID-19 pandemic at Avicenna Jagakarsa High School and to find out what factors are still lacking and need to be improved. The E-Learning Readiness model used in this research is the Aydin \& Tasci e-learning readiness (ELR) model with its rating scale grouped into four factors. These factors are human, selfdevelopment, technology, and innovation. E-learning readiness can not only be used in the preparation but also be used by organizations or institutions that have implemented e-learning. This research method used a questionnaire with a descriptive quantitative approach, namely by describing or elaborating the existing phenomena, both natural phenomena and human engineering based on the Aydin \& Tasci e-learning readiness (ELR) model. The results showed that the Avicenna Jagakarsa teacher had an e-learning readiness index, an overall ELR score of ${ }^{-} X=4.31$. This indicated that the Avicenna Jagakarsa School was ready to implement e-learning but still needed improvement.
\end{abstract}

Key Words : e-learning, e-learning readiness, ELR, covid-19

\section{PENDAHULUAN}

Adanya pandemi Covid-19 yang melanda seluruh negeri di belahan dunia termasuk Indonesia telah mengubah hampir seluruh tatanan kehidupan manusia. Covid-19 merupakan penyakit menular, yang berarti dapat menyebar, baik secara langsung maupun tidak langsung, dari satu orang ke orang lain. Virus covid-19 ini menyerang sistem pernapasan seperti hidung, tenggorokan, dan paru-paru. Rumitnya penanganan wabah dan belum ditemukannya vaksin dan obat untuk penyembuhan pasien Covid-19, serta terbatasnya alat pelindung diri (APD) untuk tenaga kesehatan membuat pemerintah menerapkan kebijakan ketat untuk memutus rantai penyebaran Covid19. Salah satu cara untuk memutus mata rantai penyebaran Covid-19 adalah dengan melakukan pembatasan interaksi masyarakat yang diterapkan dengan istilah physical distancing. Kebijakan physical distancing tersebut akan dapat 
menghambat laju pertumbuhan dalam berbagai bidang kehidupan, baik bidang ekonomi, sosial, dan juga pendidikan.

Keputusan pemerintah untuk meliburkan para peserta didik, memindahkan proses belajar mengajar di sekolah menjadi di rumah dengan menerapkan kebijakan Work From Home (WFH) membuat resah banyak pihak. WFH adalah singkatan dari work from home yang berarti bekerja dari rumah. Kebijakan WFH tertuang dalam Surat Edaran Menteri Pendayagunaan Aparatur Negara dan Reformasi Birokrasi (PAN \& RB) Nomor 50/2020 tentang Perubahan Kedua atas Surat Edaran Menteri PAN \& RB Nomor 19/2020 tentang Penyesuaian Sistem Kerja Aparatur Sipil Negara dalam Upaya Pencegahan Penyebaran Covid-19 di Lingkungan Instansi Pemerintah [1]. Sebagai ASN, guru dalam upaya melaksanakan proses pembelajaran perlu dilakukan secara online atau dalam jaringan (daring).

Pelaksanaan pembelajaran online tidak serta merta dapat langsung digunakan dalam suatu lingkungan sekolah, karena perlu adanya kesiapan kesiapan dari sekolah, guru dan juga peserta didik agar tujuan pembelajaran bisa tercapai. Kesiapan (readiness) mengarah pada suatu keadaan siap untuk berbuat sesuatu [2]. Jamies mengungkapkan kesiapan adalah "preparedness to respond or react" yang merupakan kesediaan untuk memberi respon atau bereaksi [2].

Untuk dapat memperkenalkan e-learning di suatu lingkungan organisasi harus memiliki kesiapan dalam aspek teknologi [3]. Penerapan e-learning yang sukses tidak dapat diperoleh dengan waktu yang singkat, sehingga perlu adanya pemeriksaan dan menentukan kesiapan teknologi dalam penerapan e-learning [3]. Dalam penelitian ini pengukuran kesiapan e-learning perlu diketahui untuk menganalisa faktor-faktor apa saja yang sudah kuat untuk terus dipertahankan dan faktor-faktor apa saja yang masih kurang untuk dibenahi dan ditindaklanjuti. Sehingga pelaksanaan e-learning pada masa pandemi covid-19 di SMA Avicenna Jagakarsa ini bisa maksimal.

$\begin{array}{lcr}\text { Pembelajaran } & \text { elektronik } & \text { ini } \\ \text { memungkinkan } & \text { bisa } & \text { semakin }\end{array}$ berkembangnya fleksibilitas belajar siswa yang optimal dan dapat meningkatkan kadar interaksi antara siswa dan guru [4]. E-learning adalah proses dan kegiatan penerapan pembelajaran berbasis web (web-based learning), pembelajaran berbasis komputer (computer based learning), kelas virtual (virtual classrooms), dan/atau kelas digital (digital classroom) [5]. Materi-materi dalam kegiatan pembelajaran elektronik tersebut kebanyakan dihantarkan melalui media internet, intranet, tape video atau audio, penyiaran melalui satelit, televisi interaktif serta CD-ROM. Berdasarkan beberapa pendapat tersebut, dapat disimpulkan bahwa $e$ - learning adalah pembelajaran menggunakan media teknologi informasi dan komunikasi.

E-learning adalah sebuah proses dan kegiatan penerapan pembelajaran berbasis web, komputer, kelas virtual, dan/atau kelas digital. Dengan menerapkan elearning menjadikan pembelajaran lebih fleksibel dan mengajarkan siswa untuk belajar secara mandiri. Melalui belajar mandiri akan memberikan kesempatan kepada siswa untuk lebih memahami materi pembelajaran yang sudah dirancang secara khusus dengan bantuan guru, sehingga sangat bermanfaat karena siswa dilatih mandiri agar dalam proses belajar tidak hanya tergantung pada uraian materi pembelajaran dari guru.

E-readiness didefinisikan sebagai sejauh mana suatu masyarakat siap dan memiliki 
potensi untuk berpartisipasi dalam jaringan global [6]. E-learning readiness (ELR) merupakan kesiapan mental atau fisik suatu organisasi untuk melaksanakan, melakukan tindakan dan membuat pengalaman e-learning [7]. E-learning readiness memiliki andil dalam kesuksesan program pendidikan yang menggunakan teknologi informasi dan komunikasi untuk kegiatan akademik [7]. E-learning readiness merupakan instrumen yang efektif untuk mengevaluasi efektivitas strategi organisasi dalam menerapkan $e$ learning dan menjadi dasar untuk mengevaluasi efektivitas program $e$ learning [7].

Untuk mengetahui tingkat kesiapan penerapan e-learning yaitu dengan melakukan evaluasi e-learning readiness. Salah satu model untuk melakukan evaluasi e-learning di negara berkembang adalah model Aydin \& Tascimengembangkan model ELR dengan empat faktor yang mampu mengukur kesiapan e-learning yaitu teknologi, inovasi, manusia, pengembangan diri [8].

Rumusan masalah dalam penelitian ini adalah bagaimana tingkat kesiapan Sekolah Avicenna Jagakarsa dalam penerapan e-learning pada masa pandemi covid-19 serta faktor-faktor apa saja yang masih lemah serta perlu diperbaiki atau ditingkatkan dalam penerapan e-learning pada Sekolah Avicenna Jagakarsa. Tujuan penelitian ini adalah untuk mengetahui tingkat kesiapan Sekolah Avicenna Jagakarsa dalam penerapan e-learning pada masa pandemi covid-19 dan untuk mengetahui faktor-faktor apa saja yang masih lemah serta perlu diperbaiki atau ditingkatkan dalam penerapan e-learning pada Sekolah Avicenna Jagakarsa tersebut. Manfaat dari penelitian ini adalah Untuk memberikan gambaran mengenai kategori kesiapan Sekolah Avicenna Jagakarsa dalam penerapan e-learning dan sebagai acuan Sekolah Avicenna Jagakarsa untuk mengetahui faktor-faktor apa saja yang perlu ditingkatkan atau diperbaiki dalam menunjang penerapan e-learning.

\section{METODE}

Penelitian ini merupakan penelitian deskriptif kuantitatif terhadap kesiapan SMA Avicenna Jagakarsa dalam melaksanakan e-learning pada masa pandemi covid- 19, yaitu menggambarkan fenomena-fenomena yang ada baik yang bersifat alamiah maupun rekayasa manusia. Penelitian ini menggunakan instrumen kuesioner yang dikembangkan oleh Aydin dan Tasci [8] yang terdiri dari 36 pertanyaan dan diisi oleh responden sebanyak 78 guru. Skala penilaian kuesioner menggunakan skala Likert (1-5). Selanjutnya skor rata-rata dihitung dengan menggunakan rumus:

$$
\bar{X}=\frac{\sum x}{n}
$$

Keterangan : $\bar{X}=$ rata-rata akhir

$$
\sum x=\text { jumlah skor total }
$$$$
\mathrm{n}=\text { jumlah responden }
$$

Skor rata-rata dari setiap faktor akan diukur tingkat kesiapannya berdasarkan skala pengukuran kesiapan model ELR Aydin \& Tasci [8] seperti pada gambar berikut ini.

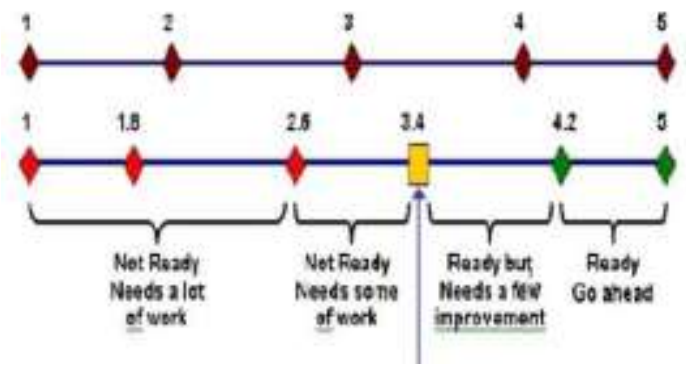

Tingkatan yang diharapkan untuk siap

Sumber : :[8]

Gambar 1. Skala Pengukuran Kesiapan ELR

Skor rata-rata 3,41 merupakan skor minimal untuk tingkat kesiapan penerapan e-learning, sehingga skor dengan nilai 
rata-rata di bawah 3,41 dianggap tidak siap dalam merapkan $e$-learning. Untuk rentang nilai dan kategori seperti pada tabel berikut ini.

Tabel 2. Skala nilai dan kategori model ELR Aydin \& Tasc

\begin{tabular}{cc}
\hline Rentang nilai & Kategori \\
\hline $1 \leq \mathrm{x} \leq 2,6$ & Tidak siap, membutuhkan banyak peningkatan \\
$2,6 \leq \mathrm{x} \leq 3,4$ & Tidak siap, membutuhkan sedikit peningkatan \\
$3,4 \leq \mathrm{x} \leq 4,2$ & Siap, tetapi membutuhkan sedikit peningkatan \\
$4,2 \leq \mathrm{x} \leq 5,0$ & Siap, penerapan - learning dapat dilanjutkan \\
\hline
\end{tabular}

\section{HASIL DAN PEMBAHASAN}

Data berupa hasil angket yang diperoleh dari responden sebanyak 78 guru kemudian dilakukan analisis dengan menggunakan model ELR model ELR Aydin \& Tasci [8]. Angket penelitian ini memiliki 36 pernyataan dengan alternatif jawaban "Sangat Setuju" dengan skor 5, "Setuju" dengan skor 4, "Netral" dengan skor 3, "Tidak setuju" dengan skor 2, dan "Sangat Tidak Setuju" dengan skor 1. Tujuan penggunaan angket pada penelitian ini adalah untuk mengetahui tingkat kesiapan penerapan E-learning di SMA Avicenna Jagakarsa.

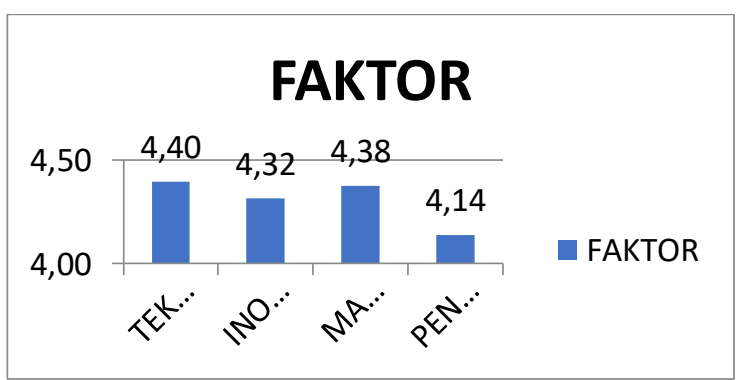

\section{Gambar 2. Grafik Hasil akhir Perhitungan ELR}

Berdasarkan pada gambar tersebut, maka dapat diketahui bahwa Sekolah Avicenna Jagakarsa mempunyai skor ELR untuk semua faktor sebesar $4,14<-\bar{X}<4,40$. Berdasarkan skala nilai dan kategori model ELR Aydin \& Tasci [8], apabila ELR $3.40<-\bar{X}<4.20$ maka dikategorikan sekolah tersebut sudah siap tetapi masih perlu adanya peningkatan untuk faktor yang masih kurang atau masih lemah, dan apabila ELR $20<\bar{X}<5.00$ maka sekolah tersebut dikategorikan sudah siap dan dapat dilanjutkan. Penelitian tentang $e$ learning readiness telah dilakukan di beberapa institusi. Penulis menganalisis beberapa penelitian terkait yang sebelumnya sudah diteliti seperti yang dilakukan di SMA Yogyakarta oleh yang berjudul Tingkat Kesiapan (Readiness) model ELR dengan mengelompokkan kesiapan ke dalam delapan kategori kesiapan [9]. Di tahun berikutnya dilakukan penelitian yang berjudul "Pengukuran Tingkat Kesiapan E-Learning (E-Learning Readiness)" menggunakan framework penelitian dengan enam komponen utama yaitu Human Resource, Kultur Organisasi, Teknologi, Kebijakan, Keadaan Keuangan Organisasi dan Infrastruktur [10]. Di tahun selanjutnya ada penelitian yang berjudul "Analisis kesiapan implementasi e-learning menggunakan e-learning readiness model", evaluasi ini menggunakan 4 faktor yaitu teknologi, inovasi, manusia, dan pengembangan diri [11].

Dari beberapa penelitian terkait yang pernah dilakukan sebelumnya, model yang penulis adopsi yaitu model ELR Aydin \& Tasci yang menggunakan empat faktor kesiapan yaitu teknologi, inovasi, manusia, dan pengembangan diri.

Model ELR Aydin \& Tasci dikembangkan untuk institusi-institusi di negara berkembang, sehingga cocok jika digunakan di Indonesia. Model ini dapat diterapkan sebelum penerapan e-learning dengan memberikan hasil skor kesiapan. 
Model ini juga dapat diterapkan sesudah penerapan e-learning dengan memberikan hasil berupa evaluasi untuk kelanjutan penerapan e-learning. Skor e-learning readiness yang sudah diketahui akan dievaluasi faktor-faktor mana saja yang masih kurang ataupun yang sudah siap dalam penerapan.

Pengukuran tingkat kesiapan penerapan ELR di Sekolah Avicenna Jagakarsa dilihat dari beberapa faktor berikut:
1. Faktor Teknologi

Pengukuran tingkat kesiapan penerapan ELR di Sekolah Avicenna Jagakarsa pada faktor teknologi dinilai dari 3 sisi yaitu sumber daya, keterampilan, dan sikap. Jumlah butir pernyataan untuk faktor teknologi adalah 11 butir yang ditunjukan pada Tabel 4.

Tabel 4. Perhitungan ELR FaktorTeknologi

\begin{tabular}{|c|c|c|c|c|}
\hline SISI & BUTIR & TOTAL & $\begin{array}{l}\text { RATA- } \\
\text { RATA }\end{array}$ & TOTAL \\
\hline \multirow{3}{*}{$\begin{array}{c}\text { Sumber } \\
\text { daya }\end{array}$} & $\overline{\mathrm{Q} 3}$ & 357 & 4,58 & \multirow{3}{*}{4,58} \\
\hline & Q4 & 360 & 4,62 & \\
\hline & Q5 & 355 & 4,55 & \\
\hline \multirow[t]{2}{*}{ Ketram } & Q7 & 340 & 4,36 & \multirow{3}{*}{4,35} \\
\hline & Q8 & 339 & 4,35 & \\
\hline \multirow[t]{6}{*}{ Sikap } & Q9 & 345 & 4,42 & \\
\hline & Q10 & 320 & 4,10 & \\
\hline & Q15 & 338 & 4,33 & \\
\hline & Q18 & 332 & 4,26 & 4,25 \\
\hline & Q19 & 328 & 4,21 & \\
\hline & Q34 & 328 & 4,21 & \\
\hline \multicolumn{4}{|c|}{ SKOR RATA-RATA FAKTOR } & 4,40 \\
\hline
\end{tabular}

2. Faktor Inovasi

Pengukuran tingkat kesiapan penerapan ELR di Sekolah Avicenna Jagakarsa pada faktor inovasi dinilai dari 3 sisi yaitu sumber daya, keterampilan, dan sikap. Jumlah butir pernyataan untuk faktor inovasi adalah 7 butir yang ditunjukan pada Tabel 5.

Tabel 5. Perhitungan ELR Faktor Inovasi

\begin{tabular}{|c|c|c|c|c|}
\hline SISI & BUTIR & TOTAL & $\begin{array}{l}\text { RATA- } \\
\text { RATA }\end{array}$ & TOTAL \\
\hline \multirow[t]{2}{*}{ Sumber daya } & Q30 & 356 & 4,56 & 4,56 \\
\hline & Q6 & 340 & 4,36 & \\
\hline \multirow[t]{3}{*}{ Ketram } & Q28 & 317 & 4,06 & 4,21 \\
\hline & Q11 & 315 & 4,04 & \\
\hline & Q12 & 328 & 4,21 & \\
\hline \multirow[t]{2}{*}{ Sikap } & Q17 & 327 & 4,19 & 4,17 \\
\hline & Q35 & 331 & 4,24 & \\
\hline \multicolumn{4}{|c|}{ SKOR RATA-RATA FAKTOR } & 4,32 \\
\hline
\end{tabular}

\section{Faktor Manusia}

Pengukuran tingkat kesiapan penerapan ELR di Sekolah Avicenna Jagakarsa pada faktor manusia dinilai dari 2 sisi yaitu sumber daya dan keterampilan. Jumlah butir pernyataan untuk faktor manusia adalah 7 butir yang hasilnya ditunjukan pada Tabel 6 . 
Tabel 6. Perhitungan ELR Faktor Manusia

\begin{tabular}{ccccc}
\hline SISI & BUTIR & TOTAL & RATA-RATA & TOTAL \\
\hline \multirow{5}{*}{ Sumber } & Q1 & 340 & 4,36 & \\
daya & Q28 & 329 & 4,22 & \\
& Q25 & 344 & 4,41 & 4,36 \\
& Q29 & 350 & 4,49 & \\
Ketram & Q26 & 350 & 4,31 & \\
& Q27 & 336 & 4,49 & 4,40 \\
& SKOR RATA-RATA FAKTOR & 4,31 \\
\hline
\end{tabular}

4. Faktor Pengembangan Diri

Pengukuran tingkat kesiapan penerapan ELR di Sekolah Avicenna Jagakarsa pada faktor pengembangan diri dinilai dari 3 sisi yaitu sumber daya, keterampilan, dan sikap. Jumlah butir pernyataan untuk faktor manusia adalah 11 butir yang ditunjukan pada Tabel 7.

Tabel 7. Perhitungan ELR Faktor Pengembangan Diri

\begin{tabular}{ccccc}
\hline SISI & BUTIR & TOTAL & RATA-RATA & TOTAL \\
\hline \multirow{6}{*}{ Sumber daya } & Q20 & 328 & 4,21 & \\
& Q21 & 329 & 4,22 & 4,24 \\
& Q22 & 334 & 4,28 & \\
Sikap & Q36 & 300 & 3,85 & 4,01 \\
& Q14 & 325 & 4,17 & \\
& Q16 & 324 & 4,15 & 4,18 \\
& Q31 & 328 & 4,21 & \\
& Q32 & 335 & 4,29 & \\
& Q33 & 324 & 4,15 & 4,14 \\
\hline
\end{tabular}

Berdasarkan hasil penelitian dan pembahasan tingkat kesiapan penerapan elearning di Sekolah Avicenna Jagakarsa dapat disimpulkan bahwa:

1. Tingkat kesiapan penerapan e-learning di Sekolah Avicenna Jagakarsa untuk semua faktor secara umum memperoleh skor 4,31 yang berarti sudah siap dalam menerapkan e-learning dan dapat dilanjutkan.

2. Tingkat kesiapan pada faktor teknologi memperoleh skor 4,40 yang berarti sudah siap dalam menerapkan $e$ learning dan dapat dilanjutkan, pada faktor inovasi memperoleh skor 4,32 yang berarti sudah siap dalam menerapkan $e$ - learning, pada faktor manusia memperoleh skor 4,38 yang berarti sudah siap dalam menerapkan $e$ learning dan dapat dilanjutkan, pada faktor pengembangan diri memperoleh skor 4,14 yang berarti sudah siap dalam menerapkan e-learning tetapi masih membutuhkan beberapa peningkatan.

3. Adapun faktor-faktor yang masih lemah atau masih kurang dan memerlukan peningkatan yaitu faktor inovasi pada sisi sikap dengan skor 4,17 dan juga pada faktor pengembangan diri pada sisi ketrampilan dengan skor 4,01 dan sisi sikap dengan skor 4,18 .

4. Pihak sekolah perlu meningkatkan sosialisasi mengenai penggunaan $e$ learning serta manfaat dari penggunaan e-learning kepada guru sehingga guru dapat beradaptasi terhadap perubahan / inovasi yang ada pada e-learning dan dapat menerapkan perubahan pembelajaran berbasis e-learning agar diterima warga sekolah. 


\section{SIMPULAN}

Dari hasil penelitian menunjukkan bahwa Sekolah Avicenna Jagakarsa telah siap dalam menerapkan e-learning akan tetapi masih perlu adanya peningkatan. Pihak sekolah disarankan untuk membentuk staff helpdesk untuk membantu guru dalam hal penggunaan $e$-learning, seperti konfigurasi jaringan untuk mengakses e-learning serta dalam hal penggunaan perangkat dan platform pada saat guru mengalami kesulitan untuk proses upload materi maupun pelaksanaan ujian serta pemberian quiz. Pihak sekolah disarankan untuk memberikan dukungan dana dan membuat rincian anggaran untuk menerapkan $e$ learning antara lain penyediaan infrastruktur jaringan internet, pengembangan aplikasi e-learning, perawatan atau maintenance e-learning serta alokasi dana untuk pengelola atau administrator e-learning yang menangani e-learning sehingga e-learning dapat diimplementasikan dengan baik.

\section{DAFTAR PUSTAKA}

[1] Instansi, Surat Edaran Menteri Pendayagunaan Aparatur Negara dan Reformasi Birokrasi (PAN \& RB) Nomor 50/2020 tentang Perubahan Kedua atas Surat Edaran Menteri PAN \& RB Nomor 19/2020 tentang Penyesuaian Sistem Kerja Aparatur Sipil Negara dalam Upaya Pencegahan Penyebaran Covid-19 di Lingkungan Instansi Pemerintah.

[2] M. Syarif. Strategi Pembelajaran. Jakarta: Rajagrafindo Persada, 2015.

[3] H. Surjono. Membangun Course ELearning Berbasis Moodle.
Yogyakarta: Yogyakarta Press, 2010.

[4] E. Siregar dan S. Dewi. Mozaik Teknologi Pendidikan. Jakarta: Prenada Media, 2004.

[5] M. Wena. Strategi Pembelajaran Inovatif Kontemporer. Malang: Bumi Aksara, 2008.

[6] Vosloo, Steve, and Jean-Paul. EGovernment and E-Readiness of Non-Profit Organisations in the Western Cape. South Africa, 2009.

[7] Priyanto. "Model E-Learning Readiness sebagai Strategi Pengembangan E-Learning". Int. Semin. Proceedings, Inf. Commun. Technol. Educ. Yogyakarta, 2009.

[8] Aydin, C. Hakan, and T. D. "Measuring Readiness for eLearning: Reflections from an Emerging country". Educational Technology \& Society, vol. 8, no. 5, 2005.

[9] H. N. Waryanto dan N. Insani, "Tingkat Kesiapan (Readiness) implementasi e-learning di Sekolah Menengah Atas Kota Yogyakarta". Jurnal Pendidikan Matematika dan Sains (JPMS), vol. 1, no. 2, 2013.

[10] A. Kurniawan. "Pengukuran Tingkat Kesiapan Penerapan E-learning Sekolah Menengah Atas Muhammadiyah di Yogyakarta". Jurnal Pendidikan Teknologi dan Kejuruan (JPTK), vol. 3, no. 5, 2014.

[11] R. Faslah dan H. B. Santoso. "Analisis Kesiapan Implementasi Elearning Menggunakan Elearning Readiness Model". Jurnal Sistem dan Teknologi Informasi, vol. 3, no. 2, pp. 113-120, 2017. 